\title{
Impact of Aqueous Extract of the Stem Bark of Anthocleista schweinfurthii Gilg (Loganiaceae) on Some Parameters of the Reproductive Function of Adult Albino Male Rats
}

\author{
Vicky Jocelyne Ama Moor ${ }^{1, *}$, Claude Venessa Kapya Ouandji ${ }^{1}$, Madeleine Chantal Ngoungoure', \\ Pascal Emmanuel Owona ${ }^{2}$, Lohik Mbolang Nguegang ${ }^{2}$, Magellan Guewo-Fokeng ${ }^{1}$, \\ Amazia Falmata ${ }^{1}$, Aggons Batakeh ${ }^{1}$, Constant Anatole Pieme ${ }^{1}$ \\ ${ }^{1}$ Department of Biochemistry, Faculty of Medicine and Biomedical Sciences, University of Yaounde I, Yaounde, Cameroon \\ ${ }^{2}$ Department of Physiology, Faculty of Sciences, University of Yaounde I, Yaounde, Cameroon
}

\author{
Email address: \\ movicky@yahoo.fr (V. J. A. Moor) \\ *Corresponding author
}

\section{To cite this article:}

Vicky Jocelyne Ama Moor, Claude Venessa Kapya Ouandji, Madeleine Chantal Ngoungoure, Pascal Emmanuel Owona, Lohik Mbolang Nguegang, Magellan Guewo-Fokeng, Amazia Falmata, Aggons Batakeh, Constant Anatole Pieme. Impact of Aqueous Extract of the Stem Bark of Anthocleista schweinfurthii Gilg (Loganiaceae) on Some Parameters of the Reproductive Function of Adult Albino Male Rats. Biochemistry and Molecular Biology. Vol. 6, No. 3, 2021, pp. 67-78. doi: 10.11648/j.bmb.20210603.15

Received: July 25, 2021; Accepted: August 5, 2021; Published: August 13, 2021

\begin{abstract}
Both modern and traditional medicine options are being practiced worldwide to alleviate and treat diseases. However, some drugs used for certain diseases have deleterious effects on other systems and functions of the body. This study aims to investigate the impact of aqueous extracts of the stem bark of Anthocleista schweinfurthii on some parameters of the reproductive function of adult albino male rats, and to perform the phytochemical screening of the extract. To achieve this objective, 18 male rats aged 60 days and weighing $150 \mathrm{~g}$ were divided into three groups of six rats each and were orally treated for 28 days with: Distilled water $(10 \mathrm{~mL} / \mathrm{kg}$ ) for group 1 (control group), aqueous extract of $A$. schweinfurthii at respective doses of 300 and $400 \mathrm{mg} / \mathrm{kg}$ for groups 2 and 3 (the two test groups). At the end of the 28-day period, the animals were anesthetized and decapitated. Blood samples were collected for serum analysis. Some androgen-dependent organs were collected and weighed. The epididymis and sperm were collected for evaluation of sperm count, mobility and viability. A sample of each organ (testis, epididymis and seminal vesicle) was homogenised for biochemical analysis and other parts were kept in Bouin's solution for histological examinations. The phytochemical screening revealed the presence of many secondary plant metabolites in the extract, including alkaloids, flavonoids and saponins. The results obtained show that the aqueous extract induced a significant reduction of the relative weight of the testis, the epididymis and the seminal vesicles. A reduction in sperm density, mobility and viability were also observed. The rates of testicular, seminal vesicle and epididymal proteins, serum cholesterol and seminal vesicle fructose decreased significantly. Otherwise, plant extracts increased testicular cholesterol concentration. Anthocleista schweinfurthii caused a significant decrease in serum gonadotrophin levels (LH, FSH) and serum testosterone concentrations and an improvement in parameters of oxidative stress. In addition, an alteration in the structure of the androgen-dependent organs was depicted on histological sections. From these findings, it is concluded that Anthocleista schweinfurthii stem bark alters some parameters of the reproductive function of adult albino male rats and suggest a limitation of their use in male subjects.
\end{abstract}

Keywords: Anthocleista schweinfurthii, Phytoestrogens, Androgens Dependent Organs, Male Rats 


\section{Introduction}

Today, living beings suffer from various diseases, with drugs being the preferred first treatment option. Human beings have always believed that drugs have the capacity to regulate diseases and have devoted the field of Medicine to ensuring the health and well-being of patients [1]. Multiple treatment options exist, for the treatment of various diseases. For a specific disease, there is the best treatment option [2]. For example, antibiotics are used to cure infections [3]; glucocorticoids are widely used in the treatment of chronic diseases because of their immunosuppressive and anti-inflammatory properties [4]. However, the clinical efficacy of certain medicines or drugs is compromised by the metabolic effects of longterm or high dose treatment and their potential for negatively affecting other body functions. This is shown in the case of dexamethasone, a glucocorticoid; high doses are known to cause a spectrum of clinical features such as obesity, insulin resistance and glucose intolerance [5] and its long-term use is associated with numerous side effects, such as the development of osteoporosis [6]. It is also known that estrogens and phytoestrogens act like anthropogenic endocrine disrupting compounds [7] and interfere with spermatogenesis and reduce sperm quality and production [8]. Anthocleista schweinfurthii, a Loganiaceae, named "Yütrùm" in Foumban, a locality in the West Cameroon, is a shrub of secondary forests. It stems bark decoction is used empirically in the treatment of stomach aches, female infertility, hernias and ovarian problems [9]. Mezui and collaborators in 2015 showed that the extract of $A$. schweinfurthii possesses significant anti-ulcer activity [10]. The extract protects the gastric mucosa even when gastric acidity is high and accelerates the healing of chronic gastric ulcer symptoms. Also, the results of the work of Ngoungoure and collaborators in 2017 showed that $A$. schweinfurthii had estrogenic properties in ovariectomized rats by reducing certain postmenopausal symptoms [11]. Consequently, within the limits of knowledge till date, there is a lack of scientific data on the impact of this plant on reproductive function of male rats. The purpose of this study was to investigate the impact of the aqueous extract of the stem bark of Anthocleista schweinfurthii Gilg (Loganiaceae) on reproductive function of adult albino male rats.

\section{Materials and Methods}

\subsection{Plant Material}

Stem bark of $A$. schweinfurthii was collected at Foumban, Western region of Cameroon, in February 2020. Authentication of this plant was done in 2002 by $\mathrm{Pr}$. ZAPFACK Louis, Botanist (systematic/ecology), Department of Vegetal Biology, University of Yaoundé I, Cameroon. The sample of the plant was identified at the national herbarium under the voucher number 9890/SRFCam.

\subsubsection{Preparation of Extract}

Stem barks were cleaned, cut in small pieces and dried at ambient temperature. Dried pieces of barks of $A$. schweinfurthii were pulverized and $160 \mathrm{~g}$ were added in $4 \mathrm{~L}$ of tap water and were boiled for $45 \mathrm{~min}$. The decoction was decanted, filtered with Watmann $\mathrm{N}^{\circ} 3$ filter paper and the filtrate evaporated in dry oven at $45^{\circ} \mathrm{C}$ and a powder of $17 \mathrm{~g}$ was obtained for an extraction yield of $10.62 \%$.

\subsubsection{Qualitative Estimation of Secondary Plant Metabolites}

Qualitative phytochemical composition of the aqueous extract of the stem bark of Anthocleista schweinfurthii was carried out according to methods described by Karumi et al., (2004) [12] for tannins, Edeoga et al., (2005) [13] for cardiac glycosides, Ayoola et al., (2008) [14] for flavonoids, reduced sugars, alkaloids, lipids, triterpenes, Nwauzoma and Dawari, (2013) [15] for steroids and Mir et al., (2013) [16] for phenols.

\subsection{Animal Material}

Male Wistar rats aged approximately 2 months and weighting about $150 \mathrm{~g}$ were obtained from Animal House of Laboratory of Animal Physiology of University of Yaoundé I. They were housed in plastic cages at room temperature under natural day/night cycle. They had free access to a standard soy-free rat diet and tap water. All the experimental protocol was undertaken in accordance with the guidelines established by the European Union on Animal Care (CEE Council 86/609) adopted by the Ethical Committee of the Cameroonian Ministry of Scientific Research and Technology Innovation (Ref. No FWA-IRD0001954).

\subsubsection{Experimental Design}

Male rats were randomly divided into three groups (A to C) comprising of six rats each. The group A (Nor $+\mathrm{H}_{2} \mathrm{O}$ ) served as the control while B (Nor +AS 300) and C (Nor +AS 400) constituted the treated groups. The extract was prepared in distilled water and orally administered to treated groups at doses of 300 and $400 \mathrm{mg} / \mathrm{kg} /$ day respectively, while distilled water $(1 \mathrm{~mL} / 100 \mathrm{~g} /$ day $)$ was given to the control groups for 28 days. Body weights were recorded weekly throughout the treatment period and before sacrifice.

\subsubsection{Serum Collection}

Sacrifice of rats under anaesthesia was carried on the 29th day, the next day after the termination of the whole experiments following over-night fasting of the animals. After sacrifice, blood samples were collected from the jugular vessels into clean and dry centrifugation tubes. The blood samples were centrifuged at $3000 \mathrm{rpm}$ for 15 minutes and different sera were aspirated with pipettes into clean and dry Eppendorf tubes and stored at a temperature at $-20^{\circ} \mathrm{C}$ for further biochemical analysis (proteins, cholesterol, LH, FSH, testosterone).

\subsubsection{Tissues Collection}

Thereafter, the rats were quickly dissected. The testis, the 
seminal vesicles and the epididymis were taken and rinsed with physiological solution $(\mathrm{NaCl} 0.9 \%$ ). These organs were cleaned of superficial fatty layer and weighed using 4-digital electronic balance (Mettler PL301) for the determination of the testis/body, seminal vesicles/body and epididymis/body weight ratio. A part of the testis, epididymis and seminal vesicles were fixed in Bouin's fluid for histology investigations and other parts were used for preparation of homogenates.

\subsubsection{Epididymal Sperm Motility, Viability and Counts}

Epididymal sperm counts were performed to assess the rats' reproductive status. Shortly after dissection, about $6 \mathrm{~mm}$ length of the caudal epididymal tissue was cut into small pieces in a stemmed glass containing $10 \mathrm{~mL}$ of $\mathrm{NaCl} 0.9 \%$ solution and incubated in a water bath at $34^{\circ} \mathrm{C}$ temperature. This sperm was further used for determination of some sperm characteristics:

\section{(i) Sperm Count and Mobility}

A volume of $20 \mu \mathrm{l}$ of the sperm suspension was aspirated and deposited on a Malassez cell. It was observed in a photonic microscope (OLYMPUS JAPAN), X 400 and the number of spermatozoa (mobile and immobile) was rapidly counted in five randomly selected quadrants [17]. Quota of mobile spermatozoa was calculated using the following formula:

$\%$ Mobility $=($ Mobile sperm $/$ Total number of sperm $) \times 100$

The number of spermatozoa per $\mathrm{mL}$ of sperm $(\mathrm{N})$ was calculated using the following formula according to Sultan et al., 1982, [18].

$$
\text { Sperm count }=\frac{X \times d f \times 10^{2}}{4}
$$

$\mathrm{X}=$ sperm count in 4 randomly selected quadrants of the Malassez's cell

$\mathrm{df}=$ dilution factor (20).

\section{(ii) Sperm Viability}

Sperm viability assessed from eosin staining that discriminate life sperm from dead sperm by staining cytoplasm of cell. A volume of $20 \mu \mathrm{L}$ of the sperm sample previously obtained was placed on a microscopic slide and $10 \mu \mathrm{L}$ of eosin $0.5 \%$ added to it and then covered with a slide and observed with light microscope X 400. A total of 100 sperm were counted within 2 minutes after the addition of the stain. Evaluation of live (unstained) and necrospermic (stained) spermatozoa were done with light microscopy according to the method described by Talebi and collaborators in 2007 [19].

\subsubsection{Preparation of Homogenates}

$0.4 \mathrm{~g}$ of testis sample was ground in a mortar and homogenised at $20 \%$ in the phosphate sodium buffer, $\mathrm{pH}$ $=7.4$ on an ice tray. $0.4 \mathrm{~g}$ of epididymis was also ground in a mortar and homogenised in a phosphate potassium buffer, $\mathrm{pH}$ $=6.8$, at $20 \%$ on an ice tray. A part of seminal vesicle tissue was ground in a mortar too and homogenised at $25 \%$ in distilled water on ambient temperature. Then, the homogenates were centrifuged for $25 \mathrm{~min}$ at 3,000 rpm maintaining the temperature at $4^{\circ} \mathrm{C}$. The supernatant obtained was assayed and stored at $-20^{\circ} \mathrm{C}$ for the estimation of both biochemical analysis including oxidant stress markers (CAT, SOD, GSH, NO, MDA), total protein, testicular cholesterol and seminal fructose.

\subsection{Biochemical Analysis}

Total protein levels were determined using colorimetric methods described by Gornall and collaborators (1949) [20]. Assay kit was used to determine total cholesterol level. This kit was supplied by BIOLABO SAS, France.

The FSH SA ELISA and Testosterone ELISA kits were intended for the quantitative measurement of Follicle Stimulating Hormone (FSH) and testosterone respectively. These kits were supplied by CALBIOTECH, a life science company, El Cajon, California. The LH ELISA kit was used for quantitative determination of Luteinizing Hormone (LH). This kit was supplied by Dialab Company, Austria.

Fructose levels were determined in seminal vesicle following protocols described in a WHO manual [21].

Reduced glutathione (GSH) was assessed using the method described by Ellman, (1959) [22] and results were expressed as $\mathrm{Mmol} \mathrm{GSH} / \mathrm{g}$ protein. Lipid peroxidation levels in homogenates were estimated using the procedure described by Wilbur and collaborators (1949) [23] and results were expressed as $\mathrm{Mmol} \mathrm{MDA} / \mathrm{g}$ of organ. Superoxide dismutase (SOD) was assayed by following the method of Misra and Frisovich, (1978) [24]. The enzyme unit of activity was defined, as the enzyme required for $50 \%$ inhibition of epinephrine auto-oxidation. Catalase is a ferriheme-containing enzyme that is responsible for the conversion of hydrogen peroxide (but not other peroxides) to water [25]. This activity was measured by the method of Aebi (1974) and was expressed as $\mathrm{mM}$ of $\mathrm{H}_{2} \mathrm{O}_{2} / \mathrm{min} / \mathrm{g}$ of protein [26]. Nitrites levels were assayed following the Griess reaction [27].

\subsection{Histological Investigation}

After measuring the weight of each organ sample for two weeks, a Bouin fixation for the testicular, seminal vesicle and epididymis tissues was performed to determine histological changes in the organs following treatment with distilled water or aqueous extract of $A$. schweinfurthii. Fixed tissues were dehydrated using a series of graded alcohol mixtures. The dehydrated tissue was then cleared in xylene for two hours and thirty minutes. Tissues were then embedded in paraffin and were cut at a thickness of $5 \mu \mathrm{m}$ using a microtome (Reichert- Jung 2030). Sections of tissues were mounted on slides and stained by immersing them in Mayer hematoxylin solution. The slides were rinsed under running tap water to remove excess hematoxylin, dipped in alcohol, eosin solution and then dehydrated through a series of graded alcohols and cleared in xylene. Finally, the tissues were mounted under a synthetic resin. Microscopic evaluation of the slides was undertaken and variations in histo-architecture were recorded [28]. 


\subsection{Statistical Analysis}

Statistical analysis was carried out using Graphpad Prism 8.0.1.244 software. Data are presented as mean \pm standard error of mean (SEM). Results were assessed using one-way analysis of variance (ANOVA) followed by the Tukey posthoc test. A probability level less than 0.05 was accepted as significance.

\section{Results}

\subsection{Qualitative Phytochemical Analysis of the Aqueous Extract of Anthocleista Schweinfurthii}

The qualitative phytochemical screening carried out on Anthocleista schweinfurthii stem bark aqueous extract revealed that it contained alkaloids, flavonoids, saponins, reduced sugars, tannins, phenols, steroids and triterpenes but not glycosides and lipids (Table 1).

Table 1. Phytochemical screening of aqueous extract of Anthocleista schweinfurthii.

\begin{tabular}{ll}
\hline Tests & Results \\
\hline Tannins & + \\
Phenols & + \\
Alkaloids & + \\
Cardiac glycosides & - \\
Flavonoids & + \\
Lipids & - \\
Saponins & + \\
Steroids & + \\
Triterpenes & + \\
\hline
\end{tabular}

$(+)$ : presence; $(-)$ : absent.

\subsection{Effect of Anthocleista Schweinfurthii Aqueous Extract on Percentage of Weight Gain}

The graphic representation (Figure 1) shows the results of weight gain. There was no significant diference in weight gain observed between extract-treated groups and their controls receiving distilled water.

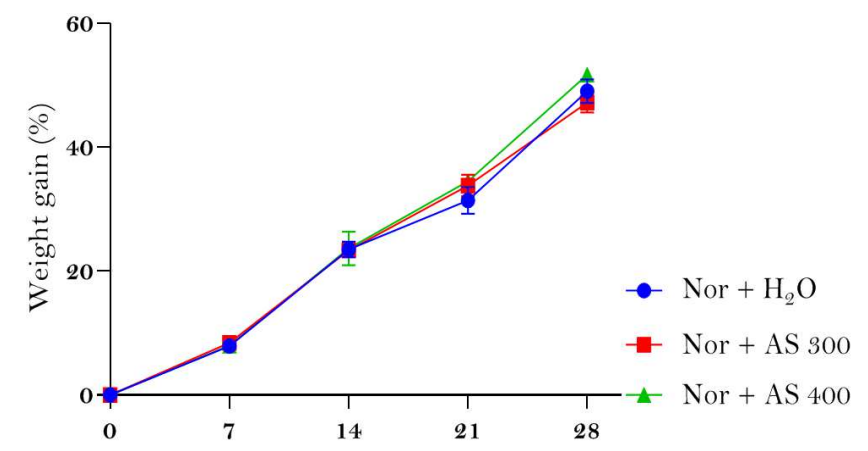

Figure 1. Effect of Anthocleista schweinfurthii aqueous extract on percentage of weight gain, $n=6 /$ group. Each point represents the mean \pm SEM (standard error of the mean of group). Nor $+\mathrm{H}_{2} \mathrm{O}=$ normal animals treated with distilled water (control group), Nor $+A S 300$ and Nor $+A S 400$ = normal animals treated with A. schweinfurthii aqueous extract at the doses of 300 and $400 \mathrm{mg} / \mathrm{kg}$ respectively.

\subsection{Effects of Anthocleista Schweinfurthii Extract on Relative Weight of the Testes, the Epididymis and the Seminal Vesicles}

The effects of $A$. schweinfurthii on the relative weight of the testes, the epididymis and the seminal vesicles are summarised in figure 2 . The treatment with $A$. schweinffurthii aqueous extract during 28 days induced a dose dependent decreasing effect on certain sexual organs relative weight. We observed at doses of $300 \mathrm{mg} / \mathrm{kg}$ and $400 \mathrm{mg} / \mathrm{kg}$, a significant lowering of the relative weight of testis $(\mathrm{p}<0.005$ and $\mathrm{p}<0.001$ respectively) and epididymis $(\mathrm{P}<0.002$ and $\mathrm{p}$ $<0,001$ respectively) compared to the control group. Nevertheless, treatment with the plant extract for 28 days induced a decrease in seminal vesicle relative weight at the dose of $400 \mathrm{mg} / \mathrm{kg}$. However, the reduction was not significant in comparison to their control group receiving placebo (distilled water).

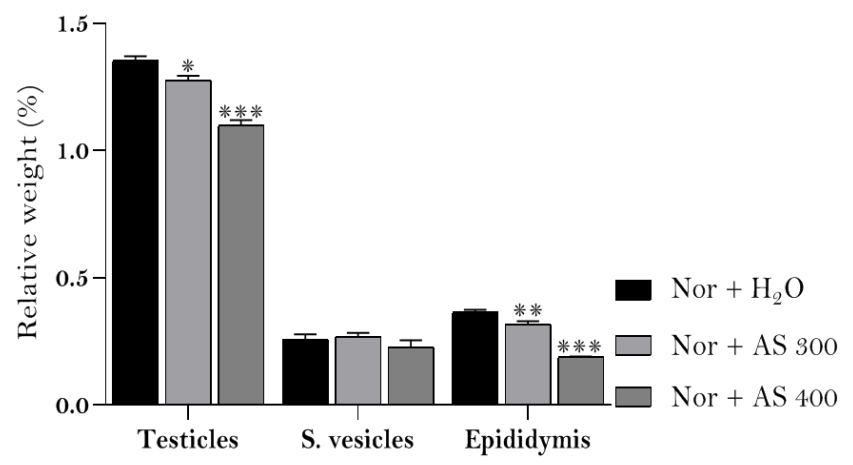

Figure 2. Effects of Anthocleista schweinfurthii extract on relative weight of the testes, the epididymis and the seminal vesicles.

Data are shown as means $\pm \mathrm{SEM}, \mathrm{n}=6$ /group. ${ }^{*} \mathrm{p}<0,05 ; * * \mathrm{p}<0,01 ; * * * \mathrm{p}<$ 0,001: statistically significant compared with Nor $+\mathrm{H}_{2} \mathrm{O}$. Nor $+\mathrm{H}_{2} \mathrm{O}=$ normal animals treated with distilled water (control group), Nor + AS 300 and Nor + AS $400=$ normal animals treated with A. schweinfurthii aqueous extract at the doses of 300 and $400 \mathrm{mg} / \mathrm{kg}$ respectively.

\subsection{Effects of Anthocleista Schweinfurthii on Caudal Epididymis Sperm Count, Viability and Motility}

Concerning semen analysis, it was found that oral administration of $A$. schweinfurthii extract at $300 \mathrm{mg} / \mathrm{Kg}$ and $400 \mathrm{mg} / \mathrm{kg}$ to adult male rats induced a significant decrease of the sperm count, sperm motility and viability (Figure 3).

\subsubsection{Epididymal Sperm Count}

Epididymal sperm counts were decreased in $A$. schweinfurthii treated rats as compared to distilled water treated rats (control group). Indeed, the treatment with $A$. schweinfurthii at doses of $300 \mathrm{mg} / \mathrm{kg}$ and $400 \mathrm{mg} / \mathrm{kg}$ induced a significant decrease in number of caudal epididymal spermatozoa ( $\mathrm{p}<0.033$ and $\mathrm{p}<0.001$ respectively) in relation to control group (Figure $3 \mathrm{~A}$ ).

\subsubsection{Sperm Motility}

Figure 3B shows the percentages of motile sperms from all groups. Rats that were treated with A. schweinfurthii at the 
both doses presented a significantly lower percentage of motile sperms compared to control group $(\mathrm{p}<0.001)$.

\subsubsection{Sperm Viability}

The administration of $A$. schweinfurthii stem bark aqueous extract induced a significant decrease in sperm viability of animals treated with the $300 \mathrm{mg} / \mathrm{kg}$ dose $(\mathrm{p}<0.002)$ and with the $400 \mathrm{mg} / \mathrm{kg}$ dose $(\mathrm{p}<0.001)$ compared to control group (Figure 3C).

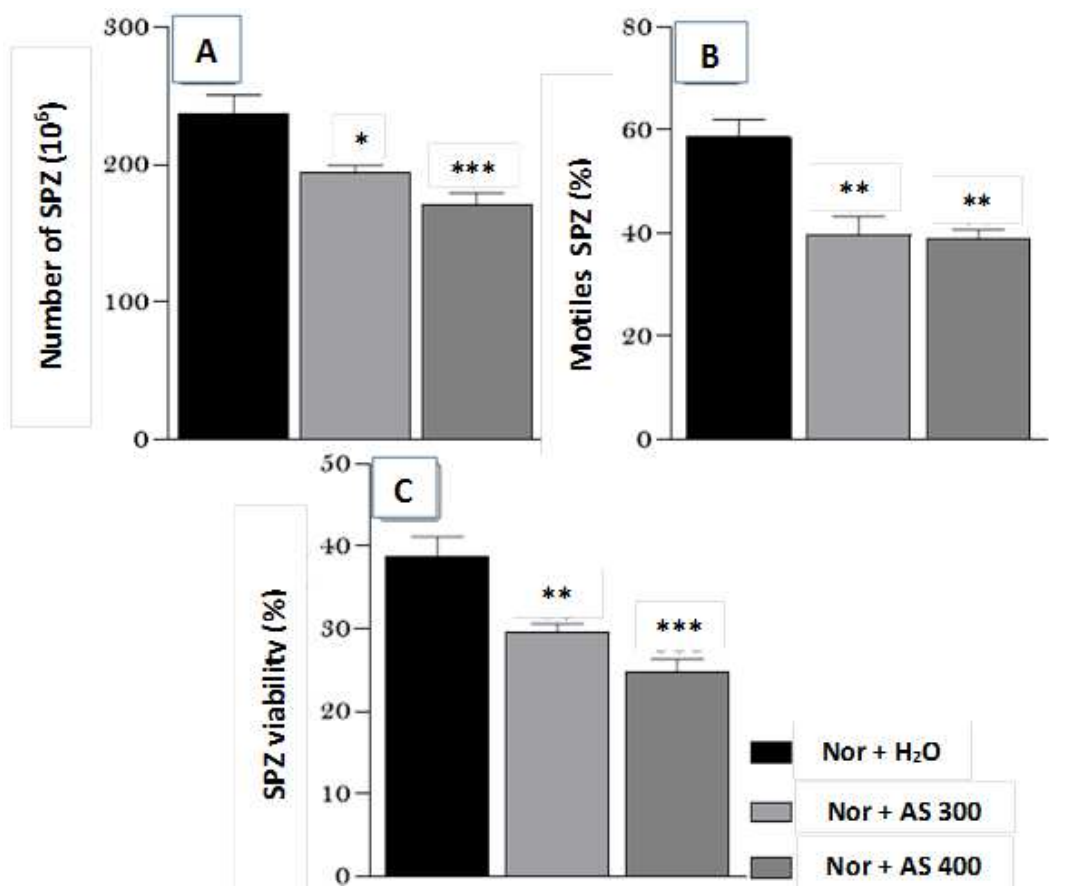

Figure 3. Effects of Anthocleista schweinfurthii on caudal epididymis sperm count, viability and motility.

Data are shown as means $\pm \mathrm{SEM}, \mathrm{n}=6$ /group. ${ }^{*} \mathrm{p}<0.005 ; *{ }^{*} \mathrm{p}<0.01 ; * * * \mathrm{p}<0.001$ : statistically significant compared with Nor $+\mathrm{H}_{2} \mathrm{O}$. Nor $+\mathrm{H}_{2} \mathrm{O}=$ normal animals treated with distilled water (control group), Nor + AS 300 and Nor + AS $400=$ normal animals treated with Anthocleista schweinfurthii aqueous extract at the doses of 300 and $400 \mathrm{mg} / \mathrm{kg}$ respectively, $\mathrm{SPZ}=$ Spermatozoa.

\subsection{Effects of Anthocleista Schweinfurthii Extract on Total Proteins}

The figure 4 below shows the effects of oral administration of A. schweinfurthii aqueous extract on total proteins concentration in the serum (Figure 4A) and in androgendependent organs (Figure 4B). The treatment with plant extract for 28 days at the doses of $300 \mathrm{mg} / \mathrm{kg}$ and $400 \mathrm{mg} / \mathrm{kg}$ induced a significant reduction $(\mathrm{p}<0.002$ and $\mathrm{p}<0.001$ respectively) in total proteins concentration in comparison to the control group receiving distilled water. Total protein concentrations in testis were significantly reduced $(\mathrm{P}<$ 0.001 ) in animals treated with plant extract at the dose of 300 $\mathrm{mg} / \mathrm{kg}$ in comparison to control group while the dose of 400 $\mathrm{mg} / \mathrm{kg}$ induced a significant decrease $(\mathrm{p}<0.002)$ in total protein concentration in seminal vesicles and in epididymis.
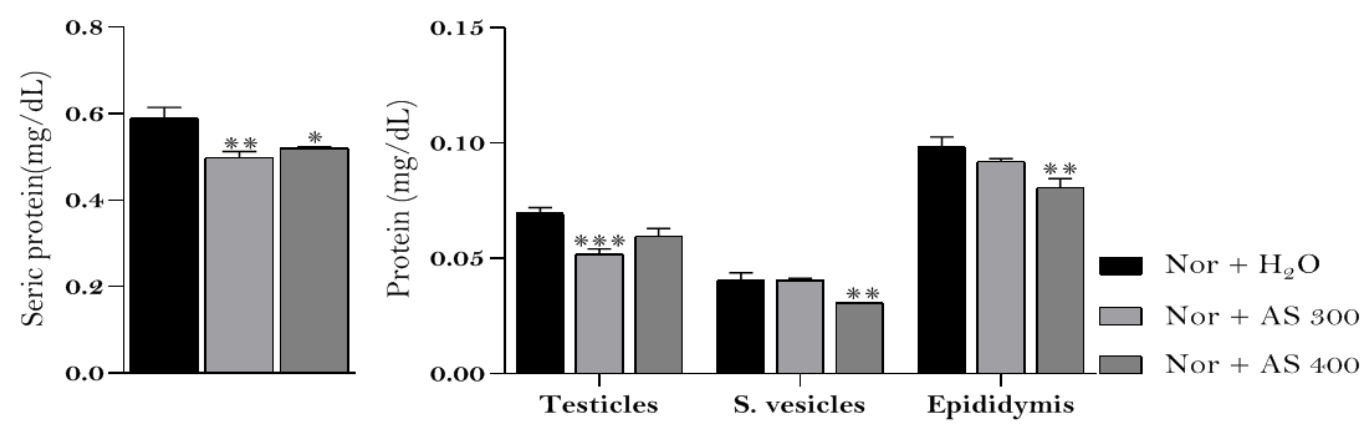

Figure 4. Effects of Anthocleista schweinfurthii extract on total proteins.

Data are shown as means $\pm \mathrm{SEM}, \mathrm{n}=6$ /group. ${ }^{*} \mathrm{p}<0.05 ; * * \mathrm{p}<0.01 ; * * * p<0.001$ : statistically significant compared with $\mathrm{Nor}^{*}+\mathrm{H}_{2} \mathrm{O}$. Nor $+\mathrm{H}_{2} \mathrm{O}=$ normal animals treated with distilled water (control group), Nor + AS 300 and Nor + AS $400=$ normal animals treated with Anthocleista schweinfurthii aqueous extract at the doses of 300 and $400 \mathrm{mg} / \mathrm{kg}$ respectively. 


\subsection{Effects of Anthocleista Schweinfurthii Extract on Total Cholesterol}

The effects of A. schweinfurthii extract are shown on figure 5. A. schweinfurthii at the dose of $400 \mathrm{mg} / \mathrm{kg}$ significantly reduced $(\mathrm{p}<0.001)$ serum total cholesterol concentration relative to the control group (Figure 5A). In contrast, rats that were treated with $A$. schweinfurthii at the both doses showed a significant increase of the testicular total cholesterol concentration as compared to distilled water treated animals $(\mathrm{p}<0.001)$ (Figure 5B).
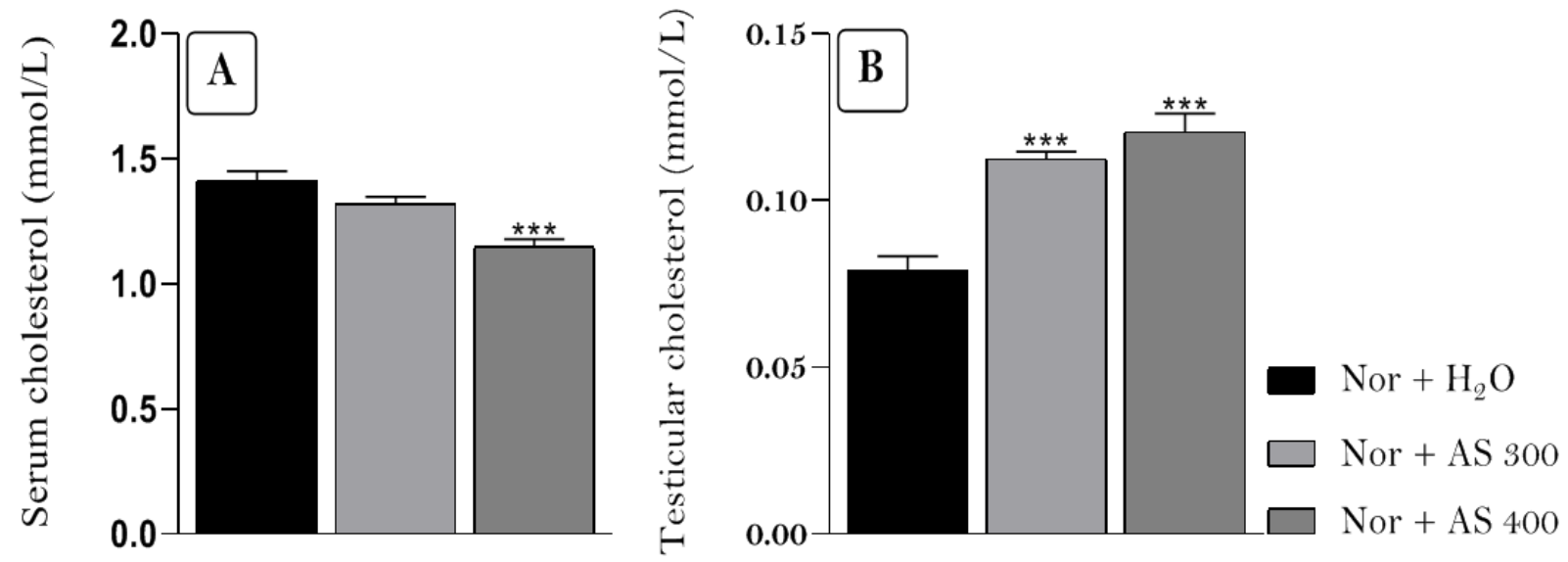

Figure 5. Effects of Anthocleista schweinfurthii extract on total cholesterol.

Data are shown as means $\pm \mathrm{SEM}, \mathrm{n}=6$ /group. ${ }^{* * *} \mathrm{p}<0.001$ : statistically significant compared with $\mathrm{Nor}+\mathrm{H}_{2} \mathrm{O}$. Nor $+\mathrm{H}_{2} \mathrm{O}=$ normal animals treated with distilled water (control group), Nor + AS 300 and Nor + AS $400=$ normal animals treated with Anthocleista schweinfurthii aqueous extract at the doses of 300 and $400 \mathrm{mg} / \mathrm{kg}$ respectively.

\subsection{Effects of Anthocleista Schweinfurthii Extract on Serum Gonadotrophin Hormones (LH, FSH) and Serum Testosterone Concentrations}

Statistically significant differences were found in the serum concentrations of both LH or FSH or in serum testosterone between the control group treated with distilled water and the group of animals treated with $A$. schweinfurthii aqueous extract at the doses of 300 and $400 \mathrm{mg} / \mathrm{kg}$ respectively (Figure 6). Indeed, A. schweinfurthii at both doses showed a significant decrease in serum LH concentration and in the serum FSH concentration $(p<0.001$ for $\mathrm{LH}$ concentration and $\mathrm{p}<0.033$ at $300 \mathrm{mg} / \mathrm{kg}$ and $\mathrm{p}<$ 0.002 at $400 \mathrm{mg} / \mathrm{kg}$ for FSH) (Figure $6 \mathrm{~A}$ ) compared to the control group. Also, the extract plant at the both doses significantly reduced serum testosterone concentration $(\mathrm{p}<$ 0.001) (Figure 6B) in comparison to animals treated with distilled water.
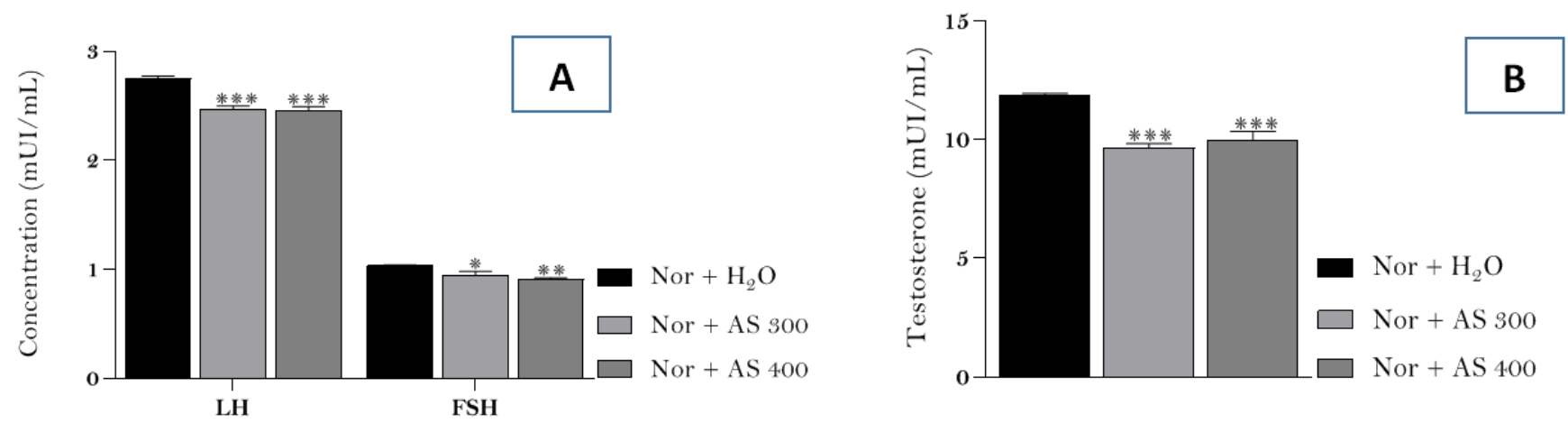

Figure 6. Effects of Anthocleista schweinfurthii extract on serum gonadotrophin hormones (LH, FSH) and serum testosterone concentrations.

Data are shown as means \pm SEM, $n=6 /$ group. ${ }^{*} \mathrm{p}<0.05 ; *$ p $<0.01 ; * *$ p $<0.001$ : statistically significant compared with $\mathrm{Nor}+\mathrm{H}_{2} \mathrm{O} . \mathrm{Nor}+\mathrm{H}_{2} \mathrm{O}=$ normal animals treated with distilled water (control group), Nor + AS 300 and Nor + AS $400=$ normal animals treated with Anthocleista schweinfurthii aqueous extract at the doses of 300 and $400 \mathrm{mg} / \mathrm{kg}$ respectively.

\subsection{Effects of Anthocleista Schweinfurthii Extract on Vesicular Fructose Level}

The aqueous extract of $A$. schweinfurthii caused a significant reduction of vesicular fructose in group Nor + AS $300(p<0.05)$ and in group Nor + AS $400(p<0.001)$ when compared to control group receiving distilled water (Figure 7). 


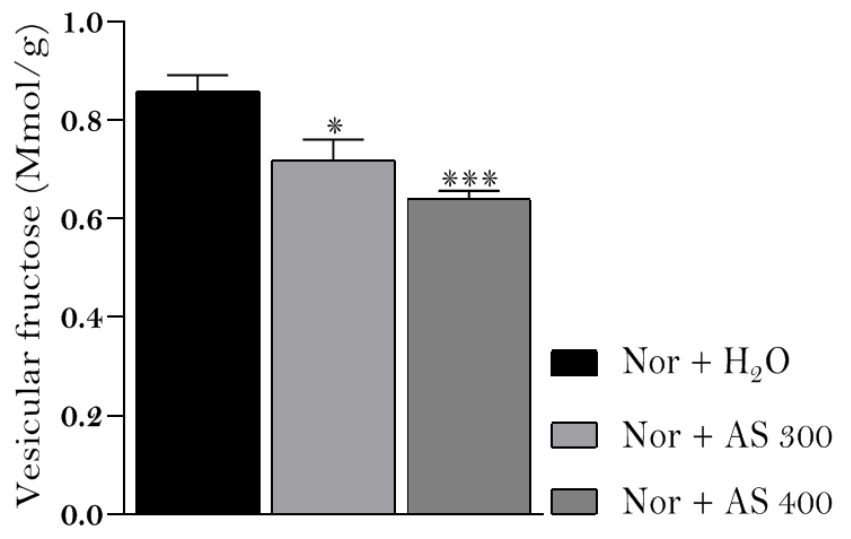

Figure 7. Effects of Anthocleista schweinfurthii extract on vesicular fructose level.

Data are shown as means \pm SEM, $\mathrm{n}=6$ /group. ${ }^{*} \mathrm{p}<0.05 ; * * * \mathrm{p}<0.001$ : statistically significant compared with Nor $+\mathrm{H}_{2} \mathrm{O}$. Nor $+\mathrm{H}_{2} \mathrm{O}=$ normal animals treated with distilled water (control group), Nor + AS 300 and Nor + AS $400=$ normal animals treated with Anthocleista schweinfurthii aqueous extract at the doses of 300 and $400 \mathrm{mg} / \mathrm{kg}$ respectively.

\subsection{Effects of Anthocleista Schweinfurthii Extract on Some Oxidative Stress Parameters}

Table 2 and Figure 8 summarise the results of $A$. schweinfurthii stem bark aqueous extract on some oxidative stress parameters in the testes, the seminal vesicles and the epididymis, notably superoxide dismutase (SOD) and catalase (CAT) activities, reduced glutathione (GSH) levels, nitrites (NO) content and malondialdehyde (MDA) levels.

Our results showed that 28 days of oral administration of A. schweinfurthii to male rats significantly increased SOD activity in testes $(\mathrm{p}<0.001)$ at the both doses as well as catalase activities in a dose-dependent manner $(\mathrm{p}<0.033$ at $300 \mathrm{mg} / \mathrm{kg}$ and $\mathrm{p}<0.001$ at $400 \mathrm{mg} / \mathrm{kg}$ ) compared to control group. At the dose of $400 \mathrm{mg} / \mathrm{kg}$, we observed a significant increase in GSH levels $(p<0.033)$ in testes in comparison to animals treated with distilled water. We also observed that in the test group, the plant extracts significantly decreased testicular MDA levels, in a dose-dependent manner ( $\mathrm{p}<$ 0.033 at $300 \mathrm{mg} / \mathrm{kg}$ and $\mathrm{p}<0.002$ at $400 \mathrm{mg} / \mathrm{kg}$ ) compared to the control group.

Concerning seminal vesicle, it was found that oral administration of $A$. schweinfurthii induced a significant lowering of MDA levels ( $\mathrm{p}<0.001$ ) at all treated doses. Also, The $400 \mathrm{mg} / \mathrm{kg}$ dose of $A$. schweinfurthii significantly decreased CAT activity $(\mathrm{p}<0.033)$ comparatively to animals treated with distilled water. Meanwhile, no statistically significant differences were found in SOD activity, GSH and nitrites levels between normal animals treated with distilled water and normal animals treated with plant extract.

In the epididymis, Treatment with $A$. schweinfurthii extracts at the two doses significantly increased GSH (p < $0.002)$ and nitrites $(\mathrm{p}<0.033$ at $300 \mathrm{mg} / \mathrm{kg}$ and $\mathrm{p}<0.002$ at $400 \mathrm{mg} / \mathrm{kg}$ ) levels versus control group. Also, we observed a significant decrease in MDA levels $(\mathrm{p}<0.001)$ at the both doses compared to control group.
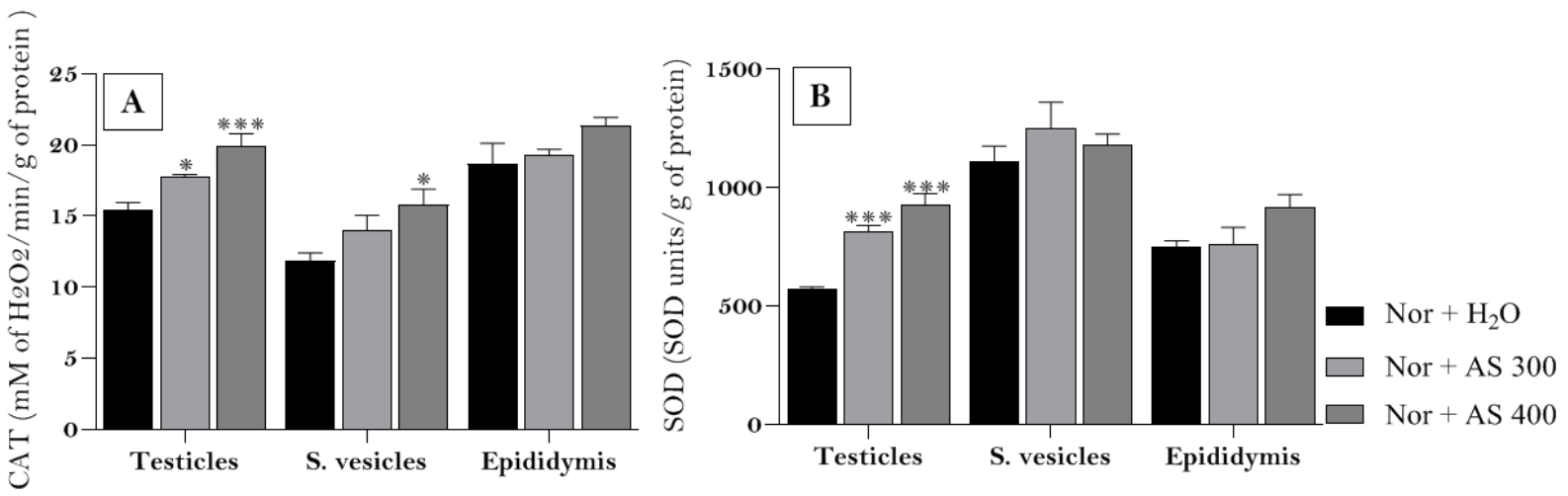

Figure 8. Effects of Anthocleista schweinfurthii extract on CAT (A) and SOD (B) in testes, seminal vesicle and epididymis.

Data are shown as means $\pm \mathrm{SEM}, \mathrm{n}=6$ /group. $* \mathrm{p}<0.05 ; * * * \mathrm{p}<0.001$ : statistically significant compared with $\mathrm{Nor}+\mathrm{H}_{2} \mathrm{O}$. Nor $+\mathrm{H}_{2} \mathrm{O}=$ normal animals treated with distilled water (control group), Nor + AS 300 and Nor + AS $400=$ normal animals treated with Anthocleista schweinfurthii aqueous extract at the doses of 300 and $400 \mathrm{mg} / \mathrm{kg}$ respectively.

Table 2. Effects of Anthocleista schweinfurthii aqueous extract on MDA, reduced glutathione (GSH), and nitrites in the testes (T), the seminal vesicle (V) and the epididymis $(E)$.

\begin{tabular}{|c|c|c|c|c|c|c|c|c|c|}
\hline \multirow{2}{*}{$\begin{array}{l}\text { Parameters } \\
\text { Groups }\end{array}$} & \multicolumn{3}{|c|}{$\begin{array}{l}\text { GSH (mmol/g of organ) } \\
\text { Mean (ST) }\end{array}$} & \multicolumn{3}{|c|}{$\begin{array}{l}\text { MDA (mmol/g of organ) } \\
\text { Mean (ST) }\end{array}$} & \multicolumn{3}{|c|}{$\begin{array}{l}\text { NITRITES (mmol/g of organ) } \\
\text { Mean (ST) }\end{array}$} \\
\hline & $\mathbf{T}$ & $\mathbf{V}$ & $\mathbf{E}$ & $\mathbf{T}$ & $\mathbf{V}$ & $\mathbf{E}$ & $\mathbf{T}$ & V & $\mathbf{E}$ \\
\hline Nor $+\mathrm{H}_{2} \mathrm{O}$ & $\begin{array}{l}0.044 \\
(0.004)\end{array}$ & $\begin{array}{l}0.021 \\
(0.001)\end{array}$ & $\begin{array}{l}0.046 \\
(0.002)\end{array}$ & $\begin{array}{l}0.451 \\
(0.0008)\end{array}$ & $\begin{array}{l}0.0096 \\
(0.0001)\end{array}$ & $\begin{array}{l}0.037 \\
(0.001)\end{array}$ & $\begin{array}{l}0.039 \\
(0.003)\end{array}$ & $\begin{array}{l}0.0095 \\
(0.0001)\end{array}$ & $\begin{array}{l}0.056 \\
(0.002)\end{array}$ \\
\hline Nor+ AS 300 & $\begin{array}{l}0.049 \\
(0.005)\end{array}$ & $\begin{array}{l}0.022 \\
(0.003)\end{array}$ & $\begin{array}{l}0.058 \\
(0.002)^{* *}\end{array}$ & $\begin{array}{l}0.0365 \\
(0.0028)^{*}\end{array}$ & $\begin{array}{l}0.0070 \\
(0.0004)^{* * *}\end{array}$ & $\begin{array}{l}0.025 \\
(0.001)^{* * *}\end{array}$ & $\begin{array}{l}0.036 \\
(0.001)\end{array}$ & $\begin{array}{l}0.0211 \\
(0.0054)\end{array}$ & $\begin{array}{l}0.065 \\
(0.001)^{*}\end{array}$ \\
\hline Nor+ AS 400 & $\begin{array}{l}0.062 \\
(0.004)^{*}\end{array}$ & $\begin{array}{l}0.020 \\
(0.001)\end{array}$ & $\begin{array}{l}0.058 \\
(0.002) * *\end{array}$ & $\begin{array}{l}0.0317 \\
(0.0023)^{* *}\end{array}$ & $\begin{array}{l}0.0073 \\
(0.0002) * * *\end{array}$ & $\begin{array}{l}0.022 \\
(0.002)^{* * *}\end{array}$ & $\begin{array}{l}0.044 \\
(0.002)\end{array}$ & $\begin{array}{l}0.0263 \\
(0.0091)\end{array}$ & $\begin{array}{l}0.068 \\
(0.001)^{* *}\end{array}$ \\
\hline
\end{tabular}

Values are shown as means $\pm \mathrm{SEM}, \mathrm{n}=6$ /group. ${ }^{*} \mathrm{p}<0.033 ; * * \mathrm{p}<0.002 ; * * * \mathrm{p}<0.001$ : statistically significant compared with Nor $+\mathrm{H}_{2} \mathrm{O}$. 


\subsection{Effects of Anthocleista Schweinfurthii Extract on the Histology of the Testis, the Seminal Vesicle and the Epididymis}

Microphotography of the testis of rats who received distilled water showed normal tissue architecture, with a normal ongoing spermatogenesis process in the seminiferous tubules.

Lumen was found to be full of spermatozoa. The testis of A. schweinfurthii treated groups presented a clearing of lumen of seminiferous tubules of in dose dependent manner, proof of an impairment of the spermatogenesis process (Figure 9).

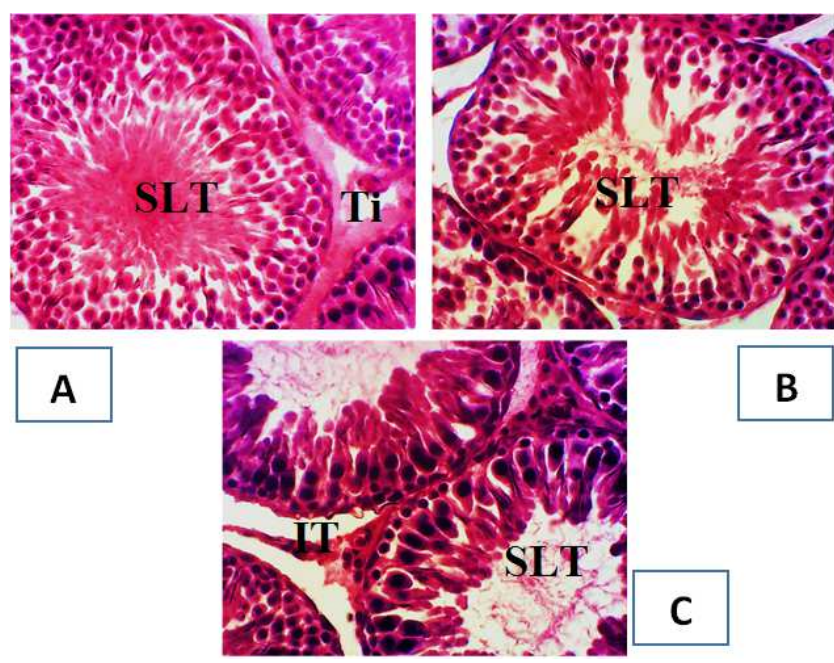

Figure 9. Effects of Anthocleista schweinfurthii extract on the histology of the testis, (H\&E., X 200). A = normal animals treated with distilled water (control group), $B$ and $C=$ normal animals treated with Anthocleista schweinfurthii aqueous extract at the doses of 300 and $400 \mathrm{mg} / \mathrm{kg}$ respectively. SLT: Seminiferous tubule lumen, IT: interstitial tissue.

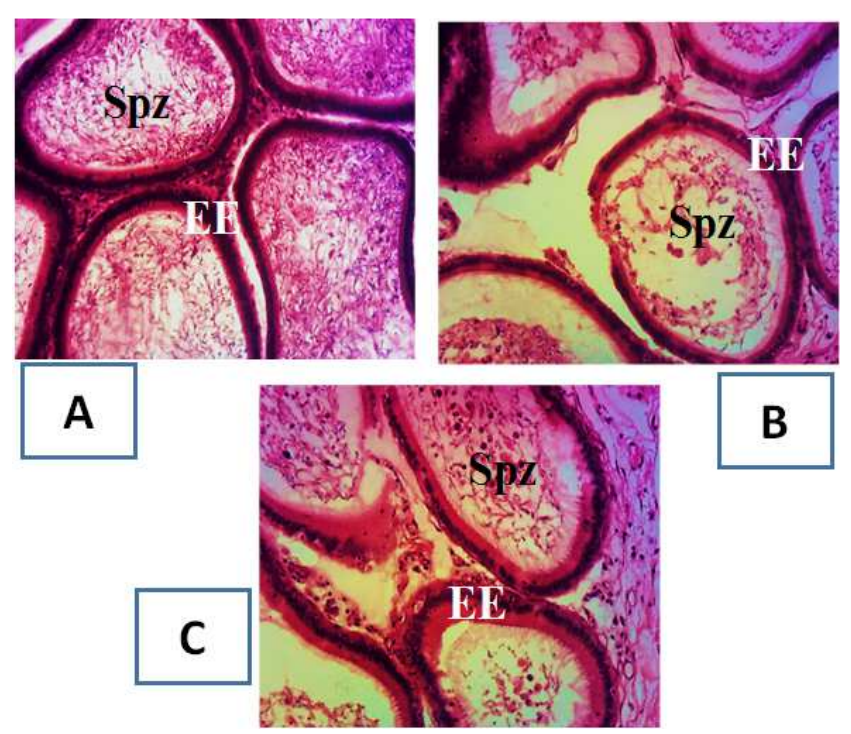

Figure 10. Effects of Anthocleista schweinfurthii extract on the histology of the epididymis, (H\&E., X 200). A = normal animals treated with distilled water (control group), $B$ and $C=$ normal animals treated with Anthocleista schweinfurthii aqueous extract at the doses of 300 and $400 \mathrm{mg} / \mathrm{kg}$ respectively. EE: Epididymal epithelium, Spz: Spermatozoid.
As shown in figure 10, the transversal section of epididymis of rats which received distilled water also exhibited a normal architecture with a lot of spermatozoa in the lumen. In the lumen of epididymal tubules of rats treated with distilled water, spermatozoa density decreased.

In the lumen of the seminal vesicle of animals treated with distilled water, we observed seminal secretions. On the other hand, there was no secretion in the lumen of seminal vesicle of animals treated with $A$. schweinfurthii at dose $400 \mathrm{mg} / \mathrm{kg}$ (Figure 11).

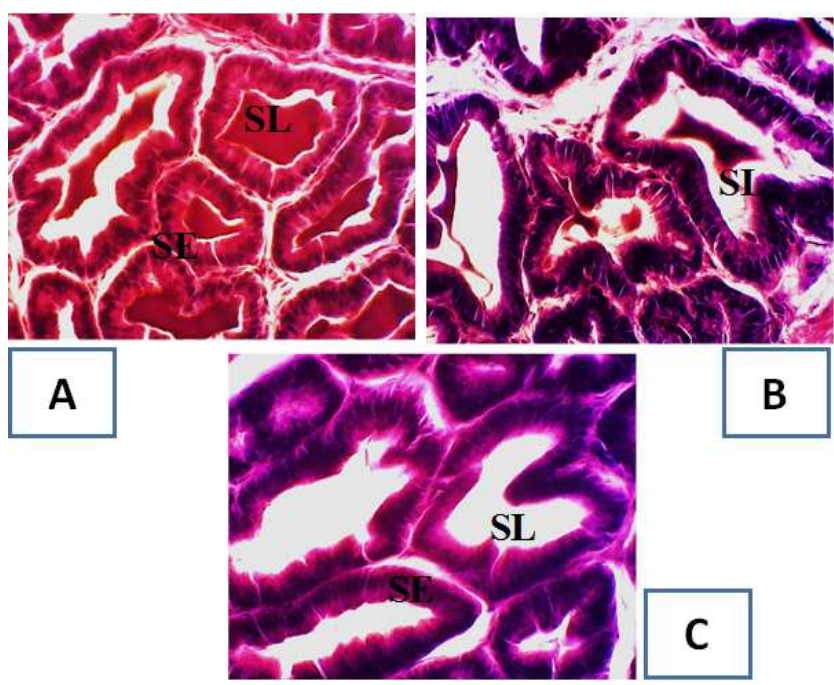

Figure 11. Effects of Anthocleista schweinfurthii extract on the histology of the seminal vesicle, $(H \& E ., X 100) . A=$ normal animals treated with distilled water (control group), $B$ and $C=$ normal animals treated with Anthocleista schweinfurthii aqueous extract at the doses of 300 and 400 $\mathrm{mg} / \mathrm{kg}$ respectively. SE: Seminal epithelium, SL: Seminal lumen.

\section{Discussion}

Herbal medicines have received greater attention as alternative to clinical therapy of many diseases and the demand for these remedies has currently increased [29], in spite of its minimal known "side-effects" on human health [30]. Number of studies have demonstrated the effect of the stem bark aqueous extract of $A$. schweinfurthi on acute and chronic gastric ulcer rats' models in rats and our previous studies [11] have shown its oestrogenic effect on some postmenopausal symptoms. This study assessed the impact of the aqueous extract of the stem bark of $A$. schweinfurthii on some parameters of the reproductive function of adult albino male rats.

The results obtained in this study showed that oral administration of $A$. schweinfurthi at doses of $300 \mathrm{mg} / \mathrm{kg}$ and $400 \mathrm{mg} / \mathrm{kg}$ for 28 days caused a significant decrease in the relative weight of the testis, the epididymis and the seminal vesicles compared to a control group. This is a reflection of the site of action of the flavonoids, a phytoestrogen compound present in aqueous extract of A. schweinfurthii, which tends to bind to both estrogen receptors types ( $\alpha$ and $\beta$ ) present within the testis, epididymis and seminal vesicle [31, 32]. The results are in accordance with the study of Gray and 
collaborators (2001) [33] which proved that substances which have an effect on androgens action can reduce testis, epididymis, seminal vesicles and prostate weight. Indeed, oestrogens and certain phytoestrogens tend to have 'demasculinising' or anti-androgenic effects which are known to interfere with androgens biosynthesis, or alter the number of androgens receptors [34-36]. The decrease in the relative organs weight observed following the administration of the plant extract might be attributed to decrease in rates of total proteins in testes, seminal vesicle and epididymis. In fact, according to Lee and Lee, (1996) [37] as well as Kouakou and Benie, (2003) [38], proteins are essentials components of cells. Therefore, its decrease could induce organ atrophy. Also, total proteins in testis and epididymis are required for spermatogenesis and sperm maturation [39]. Thus, the significant reduction in the concentration of testicular and epididymal proteins in extract plant-treated rats can lead to impaired sperm maturation. Another explanation for the decrease in relative organs' weight could be a significant reduction of sperm parameters (count, mobility and viability).

Sperm Count, motility and viability were significantly affected by $A$. schweinfurthii in treated groups. There was a drastic fall in the sperm count and reduction in percentages of progressively motile and viable spermatozoa in both dosetreated animals. In fact, a negative effect of molecules with estrogenic action-like compounds derived from plants, such as flavonoids, have been reported to directly affect male sexual functions via spermatogenesis, sperm capacitation [40-42]. It is known that A. schweinfurthii exhibited estrogenic properties because it contains flavonoids and phenols. A negative effect on spermatogenesis could be due to increasing apoptosis of developing germ cells [43] and then, a lower number of spermatozoa. Motility is one of the most important features of fertile spermatozoa, widely used as an indicator of sperm function [39]. So, the plant extract might slow down and/or inhibit the spermatogenesis process in the testis, deteriorating sperm quality in the extract-treated group. Our results suggest that $A$. schweinfurthii stem bark aqueous extract may have anti-fertility effects suggested by the drastic fall in the sperm count and reduction in percentages of progressively motile and viable spermatozoa. This anti-fertility effect of the extract plant is confirmed on microphotography of testis, epididymis and seminal secretion which showed seminiferous tubules lumen clearing, decreased lumen spermatozoa density in epididymal tubules and the absence of secretions in the lumen of seminal vesicles.

Cholesterol is a precursor of steroid hormones biosynthesis. In the present study, rats treated with $A$. schweinfurthii extract presented a significant decrease in serum total cholesterol and a significant increase in testicular cholesterol compared to control group. Several explanations are possible for significant decrease in serum total cholesterol in rats treated with $A$. schweinfurthii. One possibility is the ability of secondary metabolites of $A$. schweinfurthii to activate estrogen receptors and induce the transcription of genes involved in lipid metabolism [11]. Moreover, the aqueous extract of $A$. schweinfurthii contain saponins, which are known for their hypocholesterolemic properties [44]. This hypocholesterolemic effect may be due to the inhibition of cholesterol absorption in the intestine leading to an increase in fecal cholesterol excretion [45]. An increase in testicular cholesterol concentration may reflect reduced conversion of cholesterol to testosterone [46]. The lower concentration of testosterone is the result of estrogenic effect of our plant extract. The same result was obtained by Caceres and collaborators [47] and Corrêa and collaborators [48] respectively in 2014 and 2017 who reported that soybean phytoestrogens reduce testosterone serum concentrations.

In this study, we found a significant decrease in serum gonadotrophin hormones concentrations (LH, FSH). Indeed, Shittu and collaborators (2008) had reported that steroidogenesis and the hypothalamic-pituitary-gonadal axis may appear to be important loci for phytoestrogen actions in the brain [32]. Phytooestrogens are non-steroidal compounds that can bind to both estrogen receptor alpha and estrogen receptor beta because of their ability to mimic the conformational structure of estradiol [49] (Kuiper et al., 1998). Phytooestrogens are found in many vegetables. Thus, this result is due to the ability of estrogen or estrogen-like molecules to decrease the synthesis and/or release of gonadotrophins with the implication of both low serums [50].

Fructose is essential for spermatozoa metabolism and spermatozoa motility. Fructose is an energy source for spermatozoa [51]. Treatment with the aqueous extract at both doses decreased seminal fructose content. In fact, it has been reported by Kameni and collaborators in 2017 [8] that after ejaculation, the spermatozoa in a process named fructolysis, consume fructose. At higher sperm counts, the process is stronger resulting in a low seminal fructose concentration, suggesting that the high fructose concentrations observed in animals treated with distilled water, were released to supply motile sperm with energy after ejaculation. Another explanation for the decrease in seminal fructose is a decrease of LH concentration which affects normal function of seminal vesicles [52].

A. schweinfurthii exhibits an antioxidant property highlighted by a decrease in MDA concentration and an increase in CAT, SOD and GSH in testis, an increase of CAT and a decrease of MDA in seminal vesicle and a decrease of MDA and an increase of GSH and NO in epididymis. These results might be attributed to plant secondary metabolites flavonoids, saponins, alkaloids, phenols known for their significant antioxidant activities [53, 54] through radical scavenging, inhibition of the production of reactive oxygen species or inhibition of lipid peroxidation [55].

\section{Conclusion}

We found that there is a decrease in the relative mass of the androgen-dependent organs, impaired spermatogenesis and sperm quality, decrease of serum LH, FSH and testosterone levels and also a decrease serum cholesterol and increased 
testicular cholesterol while the rats consume this plant.

From these findings, it is concluded that Anthocleista schweinfurthii stem bark alters some parameters of the reproductive function of adult albino male rats and suggest a limitation of their use in male subjects.

\section{Research Perspectives}

We want to determine the effects on the offspring following parental exposure to the plant extract and also to determine the effects of acute administration of the plant extract on specific periods of development.

\section{Author Contribution}

Conception and design of experiments: Magellan VJAM, PEO, CVKO. Data collection: VVKO, PEO, MCN, AF, LMN. Data analysis and interpretation: VJAM, CVKO, PEO, BBA, MGF, AF, LMN, CAP. Manuscript drafting: MCN, PEO, CVKO, MCN, VJAM, BBA, MGF. Manuscript revision: VJAM, CVKO, PEO, MCN, AF, BBA, MGF, CAP. Approval of the final manuscript: All the authors.

\section{Conflict of Interest Statement}

The authors declare that they have no competing interests.

\section{Availability of Data and Materials}

The datasets used for this study are available from the corresponding author on request.

\section{Ethical Approval and Consent to Participate}

The study was approved by the Institutional Ethical Review Board of the Faculty of Medicine under the number FMSBN $^{\circ} 298 /$ UYI/FMSB/VDRC/CSD.

\section{Acknowledgements}

The authors would like to thank the staff of the biochemistry laboratory of the Yaoundé University Hospital Center, and the staff of the physiology laboratory of the University of Yaounde 1, the staff of the CIAB EXACT laboratory.

\section{References}

[1] More B (2016) Overview of Medicine- Its Importance and Impact. DJ International. J Med Res 1, 1-8.

[2] Buriani A, Garcia-Bermejo ML, Bosisio E, Xu Q, Li H, Dong X, (2012) Omic Techniques in Systems Biology Approaches to Traditional Chinese Medicine Research: Present and Future. J Ethnopharmacol 140, 535-544.
[3] Kwak YG, Choi SH, Kim T et al (2017) Clinical Guidelines for the Antibiotic Treatment for Community-Acquired Skin and Soft Tissue Infection. Infect Chemother J 49, 301-325.

[4] Franchimont D, Kino T, Galon J, Meduri GU, Chrousos G (2002) Glucocorticoids and Inflammation Revisited: The State of the Art. Neuroimmunomodulation 10, 247-260.

[5] Okwuosa CN, Unekwe PC, Achukwu PU, Udeani TKC, Ogidi UH (2011) Glucose and triglyceride lowering activity of Pterocarpus santaniloides leaf extracts against dexamethasone induced hyperlipidemia and insulin resistance in rats. Afr J Biotechnol 10, 9415-9420.

[6] Lucinda LMF, Vieira BJ, Oliveira TT et al (2010) Evidences of osteoporosis improvement in Wistar rats treated with Ginkgo biloba extract: A histomorphometric study of mandible and femur. Fitoterapia 81, 982-987.

[7] Giwercman A, (2011) Estrogens and phytoestrogens in male infertility. Curr Opin Urol 21, 519-526.

[8] Kameni PM, Dzeufiet DPD, Bilanda DC et al (2017) Effects of Nymphaea lotus Linn. (Nymphaeaceae) extract on sperm quality and reproductive function of adult albino male rats. $\mathrm{J}$ Physiol Pharmacol 21, 63-71.

[9] Kerharo J (1974) La pharmacopée Sénégalaise traditionnelle: plantes médicinales et toxiques. Edition The Book, 508-510.

[10] Mezui C, Longo F, Tan P, Nkenfou C, Fokou N, Salou H (2015) Effects of the stem barks aqueous extract of Anthocleista schweinfurthii Gilg (Loganiaceae) on acute and chronic gastric ulcer rats models. J Med Plant Res 9, 674-680.

[11] Ngoungoure MC, Bilanda DC, Dzeufiet DPD et al (2017) Oral acute toxicity and estrogenic-like effects of the aqueous extract of Anthocleista schweinfurthii Gilg (Loganiaceae). Pharmacologia 8, 9-17.

[12] Karumi Y, Onyeyili PA, Ogugbuaja VO (2004) Identification of active principles of M. balsamina (Balsam Apple) leaf extract. J Med Sci 4, 179-182.

[13] Edeoga HO, Okwu DE., Mbaebie BO, (2005) Phytochemical constituents of some Nigerian medicinal plants. Afr J Biotechnol 4, 685-688.

[14] Ayoola GA, Coker HAB, Adesegun SA et al (2008) Phytochemical Screening and Antioxidant Activities of Some Selected Medicinal Plants Used for Malaria Therapy in Southwestern Nigeria. Trop J Pharm Res 7, 1019-1024.

[15] Nwauzoma AB and Dawari Songo (2013) Study on the phytochemical properties and proximate analysis of Piper Umbellatum (LINN) from Nigeria. Am J Res Commun 1, 164-177.

[16] Mir AM, Sawhney SS, Jassal MMS (2013) Qualitative and quantitative analysis of phytochemicals of Taraxacum officinale. Wudpecker J Pharm Pharmocol 2, 1-5.

[17] Ngoula F, Wacho P, Dogmo M, Kenfack A, Kamtchouing P, Tchamboué J (2007) Effects of Pirimiphos-methyl (an organophosphate insecticide) on the fertility of adult male rats. Afr Health Sci 7, 9.20.

[18] Sultan C, Priolet G, Benzard Y, Rosa R, Josso F (1982) Techniques en hématologie. $2^{\mathrm{e}}$ ed. Flammarion Médecinescience; $15-32$. 
[19] Talebi AR, Khalili MA, Nahangi H, Abbasi A, Morteza A (2007) Evaluation of epididymal necrospermia following experimental chronic spinal cord injury in rat. Iran J Reprod Med 5, 171-176.

[20] Gornall AG, Bardawill CJ, David MM (1949) Determination of serum proteins by the means of biuret reactions. J Biol Chem 177, 751-766.

[21] OMS, (1993). Manuel de laboratoire de l'OMS: Analyse du sperme humain et de l'interaction des spermatozoïdes avec le mucus cervical. Paris: Les éditions INSERM, 85-89.

[22] Ellman GL (1959) Tissue sulfhydryl group. Arch Biochem Biophys 82, 70-77.

[23] Wilbur KM, Bernheim F, Shapiro OW (1949) The thiobarbituric acid reagent as a test for the oxidation of unsaturated fatty acids by various agents. Arch Biochem Biophys 24, 305-313.

[24] Misra HP, Frisovich I (1979) The role of superoxide anion in the antioxidant of epinephrine and simple assay for SOD. J Biolo Chem, 2457, 3170-3175.

[25] Droge W, (2002) Free radicals in the physiological control of cell function. Physiol Rev 82,47-95.

[26] Aebi H (1974) Methods of enzymatic analysis Vol 2. NewYork, NY: Academic Press, 673-678.

[27] Griess LC, Wagner DA, Glogowski J, Skippir PL, Wishnok JS, Tannenbaum SR (1982) Analysis of nitrate and [15N] nitrate in biological fluids. Anal Biochem 126, 131-138.

[28] Chauhan NS, Dixit VK (2008) Spermatogenic activity of rhizomes of Curculigo orchioides Gaertn on male rats. Int $\mathrm{J}$ Appl Res Nat Prod 1, 26-31.

[29] Otimenyin SO, Olorunfemi PO, Sabo YS, Attah SH (2013). Sub-acute toxicity studies of the herbal cough mixture (hamekof) in adult male Wister rats. J Med Med Sci 4, 439450 .

[30] Voon HC, Bhat R, Rusul G (2012) Flower extracts and their essential oils as potential antimicrobial agents for food uses and pharmaceutical applications. Compr Rev Food Sci Food Saf 11, 34-55.

[31] Saunders PT, Sharpe RM, Williams K et al (2001) Differential expression of oestrogen receptor alpha and beta proteins in the testes and male reproductive system of human and non-human primates. Mol Hum Reprod 7, 227-236.

[32] Shittu LAJ, Shittu RK, Adesite SO et al (2008) Sesame radiatum phytoestrogens stimulate spermatogenic activity and improve sperm quality in adult male Sprague Dawley rat testis. Int J Morphol 26, 643-652.

[33] Gray LE, Ostby J, Furr J, Wolf CJ, Lambright C, (2001). Effects of environmental antiandrogens on reproductive development in experimental animals. Hum Reprod Update 7, 248-264.

[34] Williams K, McKinnell C, Saunders PTK et al (2001) Neonatal exposure to potent and environmental oestrogens and abnormalities of the male reproductive system in the rat: evidence for importance of the androgen-oestrogen balance and assessment of the relevance to man. Hum Reprod Update 7, 236-247.

[35] Sharpe RM, Rivas A, Walker M, Mckinnell C, Fisher JS
(2003) Effect of neonatal treatment of rats with potent or weak (environmental) œstrogens, or with a GnRH antagonist, on Leydig cell development and function through puberty into adulthood. Int J Androl 26, 26-36.

[36] Arambula SE, Patisaul HB (2018) Endocrine Disrupting Chemicals and Behavior. Encyclopedia of Endocrine Diseases, 2nd Edition: 1-9.

[37] Lee PC and Lee W (1996) In vivo estrogenic action nonyphenol in immature rats. Bull Environ Contam Toxicol 57, 341-348.

[38] Kouakou K. and Benie T (2003). Effet antifertilisant de daldinia concentrica et psathyrella efflorescens. Recherche des effets œstrogéniques. Ethnopharmacol 31, 45-57.

[39] Mballa MF, Bilanda CD, Dzeufiet DPD et al (2017). Effects of Piper umbellatum Linn. (Piperaceae) leaves extract on aluminium chloride reproductive toxicity in male rats. World $\mathrm{J}$ Pharm Pharm Sci 6, 338-362.

[40] Cederroth CR, Auger J, Zimmermann C, Eustache F, Nef S (2010) Soy, phyto-oestrogens and male reproductive function: a review. Int J Androlo 33, 304-316.

[41] Sirotkin AV and Harrath AH (2014) Phytoestrogens and their effects. Euro J Pharmacol, 741: 230-236.

[42] Kameni PM, Dzeufiet DPD, Bilanda CD et al (2019) Nymphea lotus Linn. (Nymphaeaceae) Alleviates Sexual Disability in L-NAME Hypertensive Male Rats. Evid Based Complementary Altern Med, 1-9.

[43] Raju BA, Annapurna A, Siva RC (2009) Influence of high phytoestrogen diet on rat male reproductive system. Int $\mathrm{J}$ Pharm Technol 1, 1-20.

[44] Marrelli M, Conforti F, Araniti F, Statti GA (2016). Effects of Saponins on Lipid Metabolism: A Review of Potential Health Benefits in the Treatment of Obesity. Molecules 21, 1-20.

[45] Amany Ali MM, Tawfik MF, Hikal MS, Tag El-Din MA, (2019). Hypocholesterolemic effect of saponin extracts in experimental animals. Arab Univ J Agric Sci 26, 2463-2478.

[46] Vijaykumar B, Sangamma I, Sharanabasappa A, Patil SB (2004) Anti-spermatogenic and hormonal effects of Crotolaria juncea Linn. seed extract in male mice. Asian J Androl 6, 67-70.

[47] Caceres S, Silvan G, Martinez-Fernandez L et al (2014) The effects of isoflavones on androgens and glucocorticoids during puberty on male Wistar rats. Reprod Domest Anim 49, 611-617.

[48] Corrêa LBNS, Cardozo LFMF, Ribeiro ICA, Boaventura GT, Chagas MA (2017) Influence of prolonged flaxseed (Linum usitatissimum) consumption over epididymis and testicle histoarchitecture of Wistar rats. Pesqui Vet Bras 37, 650-656.

[49] Kuiper GG, Lemmen JG, Carlsson B et al (1998) Interaction of estrogenic chemicals and phytoestrogens with estrogen receptor beta. Endocrinology 139, 4252-4263.

[50] Brown JL and Chakraborty PK (19992). Characterization of the effects of clomiphene citrate on reproductive physiology in male rats of various ages. Acta Endocrinol 118, 437-443.

[51] Nguyen TT, Huyen VT, Nguyen TTL, Trieu TS (2018) Seminal Fructose Concentration in Man Infertility and the Fructose Test's Meaning In Diagnosis Reason of Azoospermia Man. Biomed J Sci Tech Res 8, 1-5. DOI: 10.26717/BJSTR.2018.08.001598. 
[52] Gonzales GF (2001) Function of seminal vesicles and their role in male fertility. Asian J Androl 3, 251-258.

[53] Ghasemi K., Ghasemi Y, Ebrahimzadeh MA (2009) Antioxidant activity, phenol and flavonoid contents of 13 citrus species peels and tissues. Pak J Pharm Sci 22, 277-281.
[54] Kada SA, Mieugue P, Dzeufiet DPD et al (2012) Effect of aqueous extract of Allanblakia floribunda (Olivier) stem bark on sexual behaviour in adult male rats. World J Pharm Pharm Sci 1, 585-600.

[55] Grassi D, Desideri G, Ferri C (2010) Flavonoids: antioxidants against atherosclerosis. Nutrients, 2: 889-902. 